Теоретико-практичні основи діяльності керівника у формуванні та оцінюванні професійних інтересів публічних службовців в Україні

\author{
Дмитро Осипов, Дніпропетровський регіональний інститут державного управління \\ Національної академії державного управління при Президентові України
}

У статті автором запропоновано структуру рефлексивно-акмеологічного підходу до розвитку професійних інтересів з позиції акмеології, у практичній діяльності керівників органів публічної влади та керівників публічної служби включатиме декілька аспектів: освітньо-виховного, професійно-креативного. Уточнено і розширено значення професійного виховання та оцінювання у контексті теми статті, запропоновано двофакторну модель (цикл) формування професійних інтересів публічних службовців (акмологічний підхід), а також уточнено завдання управління персоналом у галузі публічного управління як циклічного використання стимулюючого та активізуючого резервів професійних інтересів у вигляді напрямів діяльності.

Специфічними акмеологічними підходами в діагностиці (оцінюванні) професійних інтересів публічних службовців, які рекомендовано використовувати керівникам органів публічної влади та керівникам публічної служби в цих органах влади, є: предметний; проблемний; ситуаційний та системно-генетичний.

Професійне виховання як практична діяльність керівників, що передбачає розвиток у них таких якостей, як: власне суб’ єктність - сформованість життєвої позиції «діяча», «керівника»; професійна научуваність, освіченість, а відтак - професійна компетентність; терпимість як розуміння цінностей іншої людини, як визнання інакомислення; функціональну грамотність. Компонентами професійної діяльності керівника органу публічної влади або керівника публічної служби вказується: мобільність професійних вмінь та навичок; суспільна детермінація діяльності; цілісність і завершеність роботи; суб'єктна автономія; зворотний зв'язок.

Запропоновано конкретні компоненти професійної діяльності керівника органу публічної влади або керівника публічної служби, що мають компетентнісний характер, а також відповідні засоби.

Ключові слова: публічний службовець, професійні інтереси персоналу, акмеологічний підхід, керівник органу публічної влади, керівник публічної служби, професійне оиінювання, професійне виховання

\title{
Theoretical and practical bases of the head's activity in formation and estimation of professional interests of public servants in Ukraine
}

\section{Dmytro Osypov, Dnipropetrovsk Regional Institute for Public Administration National Academy for Public Administration under the President of Ukraine}

In the article, the author proposes the structure of the reflexive-acmeological approach to the development of professional interests from the position of acmeology in the practical activities of the heads of public authorities and heads of the public service, which includes several aspects: educational and educational, professional and creative.

The importance of professional education and assessment in the context of the topic of the article has been clarified and expanded, a two-factor model (cycle) of the formation of the professional interests of public servants (acmeological approach) has been proposed, and the tasks of personnel management in the field of public administration have been clarified as a cyclic use of stimulating and activating reserves of professional interests in the form of directions of activity.

It is recommended to use specific acmeological approaches in the diagnosis (assessment) of the professional interests of public servants for heads of public authorities and public service leaders: problem; situational and systemic genetic.

Professional education as a practical activity of leaders provides for the development of such qualities as: 
proper subjectivity - the formation of the life position of a «doen», «leaden»; professional learning ability, education, and therefore - professional competence; tolerance as an understanding of the values of another person, as an acknowledgment of dissent; functional literacy. The components of the professional activity of the head of a public authority or the head of the public service are: mobility of professional skills; social determination of activity; integrity and completeness of work; subjective autonomy; feedback.

Specific components of the professional activity of the head of a public authority or the head of a public service, which have a competence-based nature, as well as appropriate techniques are proposed.

Keywords: public servant, professional interests of staff, acmeological approach, head of a public authority, head of public service, professional assessment, professional education

\section{Теоретико-практические основы деятельности руководителя в формировании и оценке профессиональных интересов публичных служащих в Украине}

\section{Дмитрий Осипов, Днепропетровский региональный институт государственного управления Национальной академии государственного управления при Президенте Украины}

В статье автором предложена структура рефлексивно-акмеологического подхода к развитию профессиональных интересов с позиции акмеологии в практической деятельности руководителей органов публичной власти и руководителей публичной службы, которая включает в себя несколько аспектов: образовательно-воспитательного, профессионально-креативного.

Уточнено и расширено значение профессионального воспитания и оценки в контексте темы статьи, предложено двухфакторную модель (цикл) формирования профессиональных интересов публичных служащих (акмеологический подход), а также уточнены задачи управления персоналом в области публичного управления как циклического использования стимулирующего и активизирующего резервов профессиональных интересов в виде направлений деятельности.

Специфическими акмеологическими подходами в диагностике (оценке) профессиональных интересов публичных служащих руководителям органов публичной власти и руководителям публичной службы рекомендуется использовать: предметный; проблемный; ситуационный и системно-генетический.

Профессиональное воспитание как практическая деятельность руководителей предусматривает развитие у них таких качеств, как: собственно субъектность - сформированность жизненной позиции «деятеля», «руководителя»; профессиональная обучаемость, образованность, а поэтому профессиональную компетентность; терпимость как понимание ценностей другого человека, как признание инакомыслия; функциональная грамотность. Компонентами профессиональной деятельности руководителя органа публичной власти или руководителя публичной службы указано: мобильность профессиональных умений и навыков; общественную детерминацию деятельности; целостность и завершенность работы; субъектную автономию; обратную связь.

Предложены конкретные компоненты профессиональной деятельности руководителя органа публичной власти или руководителя публичной службы, имеющие компетентностный характер, а также соответствующие приемы.

Ключевые слова: публичный служсащий, профессиональные интересы персонала, акмеологический подход, руководитель органа публичной власти, руководитель публичной службы, профессиональное оченивание, профессиональное воспитание 
$\Phi$ ормування професійних інтересів публічних службовців є складним сполученням процесів, основними 3 яких визначено: процес формування інтересів особистості в якості публічного службовця; процес формування інтересів, професійних інтересів з боку батьків, сім'ї, закладів освіти; процес формування професійних інтересів 3 боку друзів, родичів, товаришів, знайомих, процес формування 3 боку колег, а згодом, коли колегами стають публічні службовці, - 3 боку кадрів публічної служби, і процес формування професійних інтересів в якості публічного службовця з боку населення в громадській думці.

Проблема, сформована у назві статті, ще не стала предметом комплексних наукових досліджень, однак значний внесок у дослідження різниих аспектів діяльності керівників державних та муніципальних органів влади внесли: В. Д. Бакуменко, Л. О. Воронько, Н. Т. Гончарук, В. С. Куйбіда, Н. А. Липовська, Н. Р. Нижник Ю. О. Оболенський, Л. А. Пашко, С. М. Серьогін, Л. С. Стельмащук, I. Г. Сурай, С. К. Хаджирадєва, Ю. П. Шаров, I. В. Шпекторенко. Проте конкретна діяльність керівників органу публічної влади в аспекті формування професійних інтересів підлеглих у контексті мотиваційних чинників професійного розвитку останніх з позиції акмелології не досліджувалась.

Тема даної статті: теоретико-практичні основи діяльності керівників органу публічної влади в аспекті формування професійних інтересів підлеглих у контексті мотиваційних чинників професійного розвитку персоналу.

\section{Викладення основного матеріалу.}

Структура рефлексивно-акмеологічного підходу до розвитку професійних інтересів з позиції акмеології (Акмеология, 2004; Козлова, 2008), у практичній діяльності керівників органів публічної влади та керівників публічної служби включатиме декілька аспектів: освітньо-виховного, професійно-креативного.

Освітньо-виховний аспект націлений на діагностику та розвиток професійного змісту етичності поведінки та компетентності в системі загальної (у період допрофесійно- го становлення), професійної безперервної освіти та самоосвіти публічних службовців.

Професійно-креативний аспект пов'язаний з визначенням зусиль, що витрачаються, успішністю їх реалізації визначенням можливостей і результатів здійснення трудової діяльності через з'ясування та порівняння потенціалу працівника 3 вимогами професійної придатності, мотиваційно-психологічною готовністю до професії, оцінки соціальної значущості інновацій, сформованості соціальної відповідальності за роботу, креативного ставлення до праці.

У процесі професійного розвитку та становлення сучасних публічних службовців в Україні є недооціненим професійне виховання як практична діяльність керівників, що передбачає розвиток у них таких якостей, як:

- власне суб'єктність - сформованість життєвої позиції «діяча», «керівника», яка передбачає стійке самовизначення людини, його активність і відповідальність у професійній сфері;

- професійна научуваність, освіченість, а відтак - професійна компетентність як здатність людини бути в адекватній динамічній управлінській ситуації, вміння працювати зі знанням в суспільстві, що розширюється і що змінюється;

- терпимість як розуміння цінностей іншої людини, як визнання інакомислення, усвідомлення меж своїх посадових дій та прав і свобод іншої людини, вміння комунікувати та домовлятися;

- функціональна грамотність як наявність знання про навколишній світ і мову спілкування, що забезпечує людині можливість стати господарем своєї долі.

Професійне виховання - це цілеспрямований вплив керівників, професійного середовища (різноманітних умов праці) на особистість публічного службовця 3 метою формування в ній певних професійно важливих якостей, як: прагнення до самостійності, етичність поведінки (уважність, ввічливість, товариськість, відповідальність), що допоможе самовираженню, набуттю авторитету. Виховання здійснюється за участі керівників шляхом особистого прикладу, навчання на робочому місці, бесіди, стажування, інших акмеологічних інструментів. 
У такий спосіб на практиці роботи органів публічного управління можна реалізувати принцип суб'єкта діяльності, коли особистість, функціонуючи, «органічно вписується» в інші системи життєдіяльності - професійної діяльності, спілкування, пізнання, а частиною особистісного розвитку особистості $є$ входження іiі у соціальну спільноту публічних службовців та іiі професійна діяльність у іiі індивідуальному та груповому вимірах.

Професійні інтереси у діяльності публічного службовця, процес та результат зазначеної діяльності віддзеркалюють те, настільки повно у ньому сформовано самооцінку, професійне самовизначення, професійну самоактуалізацію, професійну самоідентифікацію та самооцінку, професійну спрямованість, відповідальність.

Актуальною науково-практичною проблемою є діяльнісне вираження професійної діяльності публічних службовців, яке закріплюється у посадових інструкціях. Діяльнісне вираження професійної діяльності публічних службовців $є$ важливим тому, що воно дозволяє оцінювати сформованість етичних, поведінкових аспектів діяльності, власне результати діяльності, а відтак - міру сформованості ціннісно-орієнтаційних, потребо-мотиваційних якостей службовця (включаючи професійні наміри та інтереси), а також компетентнісну сферу (Шпекторенко, 2007, 2014). 3 результатів діяльності найкраще видно забезпеченість реалізуємості суб'єкта діяльності, те, як виступає публічний службовець у професійній ролі захисника загальних, державних, публічних інтересів, ставлення особистості до професії.

Професійне середовище органу публічної влади (матеріальні та нематеріальні умови праці, фактор II) повинне впливати на персонал у такий спосіб, аби в основі власних професійних інтересів він мав інтереси держави, публічного сектору суспільства, усіх верств суспільства, інтересах громадянина, особистості (фактор I), що відзеркалено у двофакторній моделі (циклі) формування професійних інтересів публічних службовців заснованій на теоретичних положеннях акмологічного підходу) (рис.1).

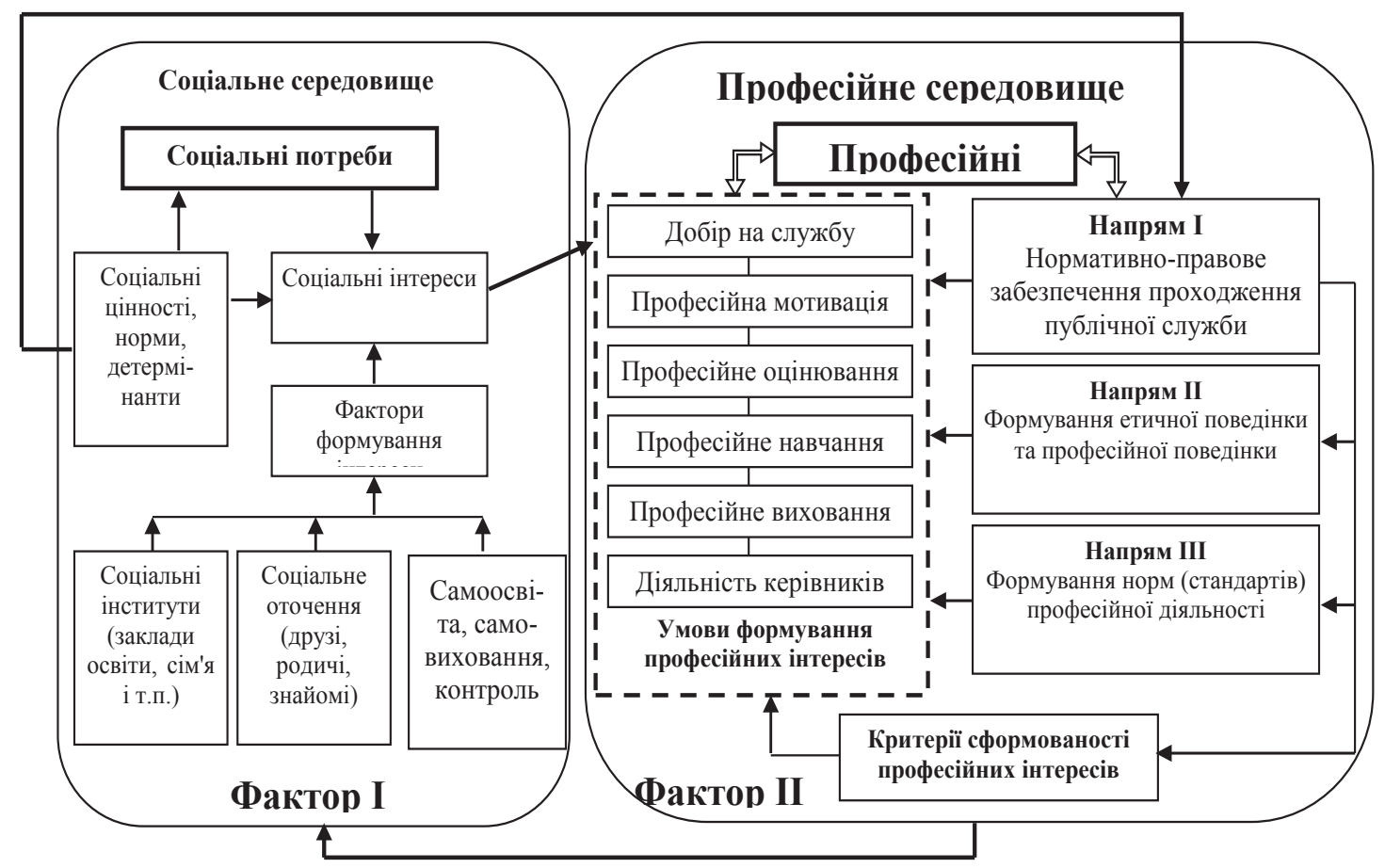

Рис. 1. Двофакторна модель (цикл) формування професійних інтересів публічних служсбовців (акмологічний nidxid) 
Професійне середовище органу публічного управління (фактор II), насамперед керівника органу та керівника публічної служби має сформувати у публічного службовця «параметри активності» або ознаки суб'єктності людини (згідно з акмеологією) (Акмеология, 2004; Федоркина):

- активна зорієнтованість (в новій професійній ситуації, матеріалі);

- усвідомлення (змісту та структури посадової діяльності, професійної компетентності, професійних та ділових якостей особистості, досвіду);

- самовизначення, ініціатива, передбачення, планування, професійна інтуїція;

- активна включеність у діяльність та реалізуємість суб'єкта діяльності;

- постійна налаштованість на саморозвиток і самовідновлення;

- здатність до саморегуляції (самокорекції, самоконтролю, самокомпенсації, самоосвіти), володіння техніками саморегуляції; розуміння протиріч свого розвитку, їх усунення, забезпечення балансу приватного та професійного життя;

- усвідомлення, критична оцінка та впорядкування свого професійного шляху, професіоналізму, професійного досвіду й досвіду інших.

Формування професійних інтересів не може бути дієвим без застосування сучасних форм і методів матеріального та нематеріального стимулювання персоналу, усунення фрустраторів, у менеджменті персоналу напрацьовані ефективні методики, які не використовуються в публічній службі України. Будь-яке заохочення повинне мати мотивуючу силу: не створювати у людини враження, що їм маніпулюють, коли людині соромно за свої вчинки; не заохочувати діяльність, яка сама по собі подобається людині і яку вона із задоволенням виконує без всяких нагород, заохочення мусить бути пов'язане 3 досягненнями; заохочувати як хороші, так і середні результати, не перетворювати заохочення в звичайну рутинну процедуру (Магура, \& Курбатова, 2007, с. 186).

Підвищення значення деяких професійних і статусних (зовнішніх) мотивів професії публічного службовця, що спостерігається нині в Україні на рівні нормативно-право- вого регулювання, не означає абсолютного зниження ролі матеріальних, нематеріальних та інших мотиваторів, стимулів та активізаторів професійної діяльності. Вони залишаються важливою, але не єдиною умовою професіоналізації, спроможною якісно підвищити професійну активність, сприяючи досягненню високих результатів індивідуальної та колективної діяльності.

Аспект сформованості професійних інтересів $\epsilon$ провідним і в професійному оцінюванні персоналу органів публічної влади. Адже і орієнтувальна, розвивальна і стимулювальна функції професійного оцінювання персоналу мають безпосередній вихід на практику мотивації професійної діяльності, а їх повноцінне дотримання виконання означених функцій у процесі управління персоналом здатне суттєво вплинути на професійну поведінку персоналу, його трудову активність.

Отже, завданням управління персоналом у галузі публічного управління є циклічне використання стимулюючого та активізуючого резервів професійних інтересів у вигляді напрямів діяльності. Послідовність запроваджуваних у цій сфері активізаційних засобів з позиції формування та оцінювання професійних інтересів, на наш погляд, повинна включати:

- нормативно-правову регламентацію впливу на зміст професійних інтересів публічних службовців, що враховує домінуючі у суспільстві соціальні норми (соціально-законодавче нормування);

- професійне оцінювання професійних інтересів разом $з$ професійною компетентністю під час конкурсного добору на публічну службу (найголовніша мета - відбір публічних службовців з акмічною спрямованістю, адекватними професійними інтересами);

- професійне оцінювання професійних інтересів під час конкурсного відбору та щорічного оцінювання публічного службовця;

- посилення матеріального і нематеріального стимулювання публічних службовців у напрямках: по-перше, формування та розвитку власне професійних інтересів, що визначаються місією, призначенням, напрямами діяльності, завданнями та відповідальністю 
органів публічної влади; по-друге, забезпечення спрямованості ідентифікаційного процесу в органі публічної влади на досягнення випереджаючого формування професійних інтересів та професійної ідентичності публічного службовця, індивідуалізації стимулів до праці за конкретні результати в професійній діяльності;

- запобігання формуванню та впливу фрустраторів у діяльності публічного службовця, а саме забезпечення персоналу публічних органів комфортними умовами праці, необхідними ресурсами, створення сприятливого морально-психологічного комфорту у групах (колективах), що є умовою здійснення його посадових обов'язків;

- розвиток зовнішніх мотиваторів у публічній службі, які б максимально відповідали мотиваційному профілю публічного службовця, його особистим (у плані соціального становлення особи, а не приватному) та професійним інтересам 3 метою створення умов для самореалізації в роботі, становлення суб'єктності, напрямів особистісно-професійного становлення працівника;

- надання максимально об'єктивної оцінки професійної діяльності, удосконалення професійної компетентності, професійної культури (в аспекті формування світогляду та професійної поведінки) та професійного досвіду, створення умов для спілкування 3 колегами, допомога споживачам управлінських послуг, і на цій основі - досягнення результативності у професійній діяльності;

- професійна орієнтація та професійне консультування з метою визначення переваг професії, формування та розвиток професійної самоідентифікації публічних службовців, блокування псевдопозитивних професійних інтересів.

Відсутність професійного оцінювання або його необ'єктивність деформують людину, не стимулюють її особистісний, посадовий та професійний розвиток, знижують насиченість, активність та результативність професійної діяльності. Оцінювання персоналу - справа професіоналів, починати іiі потрібно з теоретичного обгрунтування, узагальнення передового досвіду, підготовки відповідних рекомендацій та професіоналізму діяльності керівників органів публічної 76 влади та керівників публічної служби. Стимулювання персоналу у практиці роботи 3 кадрами державної служби в Україні потрібно розглядати як складову мотиваційного процесу, вияв зовнішньої мотивації, котру здійснює щодо персоналу адміністрація органу публічної влади.

Специфічними акмеологічними підходами в діагностиці (оцінюванні) професійних інтересів публічних службовців, які рекомендовано використовувати керівникам органів публічної влади та керівникам публічної служби в цих органах влади:

- предметний, коли професійні інтереси оцінюються у всій їх сукупності та ієрархії станом на певний момент (професійний відбір, щорічне оцінювання, поточні розмови, співбесіди);

- проблемний, коли професійні інтереси аналогічно до предметного підходу оцінюються та аналізуються в ситуаціях професійних деформацій та деструкцій у публічних службовців, негативних проявах ставлення до посадових обов'язків, етичності та професійної поведінки, падіння результативності праці. Мета такого оцінювання - з'ясування проблем у мотиваційній сфері та потенціалі особистості, мотиваційному полі;

- ситуаційний, цей підхід є майже аналогічним за змістом 3 проблемним, і може поєднуватися 3 проблемним, застосовуючись у ситуаціях коли публічний службовець, не маючи значних проблем у розвитку мотиваційної сфери та потенціалі в цілому, має вади їх розвитку в конкретних професійних ситуаціях;

- системно-генетичний, коли дослідження професійних змісту, спрямованості та ієрархії професійних інтересів відбуваються комплексно та в динаміці, охоплюючи значні періоди професійного життя, починаючи зі вступу на публічну службу.

У процесі формування професійних інтересів керівники повинні знати та враховувати специфічні риси професійного профілю публічного службовця, що відображає його найголовніші професійно важливі та ділові якості. Відомо, що професію публічного службовця обирають люди 3 соціальною роллю бути корисними людям, бути на виду, мати вплив на людей, бути впливовими. 
Це - люди з людиноцентричним підходом, які у кожному споживачеві управлінських послуг бачать насамперед людину, поважають їі як особистість, допомагають вирішити проблеми, з якими вона звернулась до органу публічної влади. У розвинених країнах на роботу у публічному управлінні персонал часто влаштовується після політичної, бізнесової діяльності, безкоштовної роботи громадськими волонтерами, консультантами, помічниками. Часто вищою винагородою такі публічні службовці вважають для себе позитивний соціально-політичний, соціально-економічний ефект від своєї управлінської діяльності. Нерідко грошова винагорода такими працівниками сприймається як задоволення їхніх морально-етичних інтересів, що відповідають цінностям та настановам.

Такими компонентами професійної діяльності керівника органу публічної влади або керівника публічної служби є:

- мобільність професійних вмінь та навичок (професійна научуваність як якість персоналу): розширення посадової компетенції, збагачення змісту роботи, розширення та делегування повноважень, насичення iii інноваційними, нестандартними складовими, що посилюють інтерес публічного службовця до роботи. (На думку низки дослідників професіоналізм особи також повинен містити професійні стандарти, орієнтуючі на високу якість виконання діяльності, - «професіонал своєї справи», систему моральних норм регуляції поведінки, професіоналів роблять, певною мірою, особами винятковими. Таким чином, професіоналізм накладає на суб'єкта праці певні жорсткі зобов'язання, що відбивають не лише якість діяльності, але і що впливають на систему його стосунків. Іншими словами, професіонал завжди та у всьому обмежений рамками високих стандартів (Зазыкин);

- суспільна детермінація діяльності, престижність праці; формування у службовця відчуття важливості, значущості своєї роботи;

- цілісність і завершеність роботи: доручення підлеглому конкретного завдання в повному обсязі, що надасть йому можливість мати задоволення від результатів роботи. Для публічних службовців це актуально, оскільки згідно зі специфікою адміністративної послуги бажано, щоб ії̈ надавали одні й ті самі працівники аж до одержання необхідного результату;

- суб'єктна автономія: звільнення підлеглих від дріб'язкового опікування, надто детального контролю, надання їм самостійності;

- зворотний зв'язок: обговорення 3 підлеглим шляхів реалізації конкретного завдання та результатів його виконання. Виявляючи постійний інтерес до роботи підлеглого, керівник сприяє її успішному виконанню.

Зазначені елементи змісту та організації праці формують особливий психологічний стан у підлеглих: усвідомлення відповідальності, інтересу, успіху, значущості та ін. Вони безпосередньо впливають на посилення активності публічного службовця. При цьому суттєвим $є$ те, що мотивація, що виникає внаслідок застосування цього методу, реально стає внутрішнім фактором, який сприяє підвищенню якості роботи, задоволеності працею, посилює потребу в удосконаленні професійної компетентності, мінімізації плинності персоналу, поліпшує соціально-психологічний клімат у колективі. Як зазначає В. Д. Севостьянов: «У той же час керівник, який спрямовується головним чином широкими соціальними мотивами, перш за все зацікавлений в створення стабільного та дієздатного колективу, і буде непримиренним із плинністю кадрів» (Севостьянов, 2016, с. 101).

Для персоналу публічної служби винятково важливими $є$ засоби задоволення професійних інтересів, оскільки для професійної групи вони є пріоритетними. До цих засобів, які керівник органу публічної влади або керівник публічної служби повинні застосовувати, належать:

- формування духу «єдиної команди», критеріями якого $є$ : колективістичне самовизначення, колективістична ідентифікація, конформність, ціннісно-орієнтаційна єдність, групова згуртованість, соціально-психологічний клімат;

- організація нарад, семінарів, конференцій $з$ питань публічного управління певною галуззю для надання можливості 
задоволення потреб у спілкуванні, обміні професійним досвідом, розробці нових ідей, формуванні світогляду, цінностей, норм, професійної культури та поведінки;

- формування компонентів адміністративної культури в органах публічної влади (самоідентифікації, відчуття належності і причетності до професії, органу публічної влади, формування специфічних морально-етичних норм, правил, цінностей в органах влади);

- реалістичне й чітке роз'яснення відносин, що можуть призводити до ситуації конфлікту інтересів, розробка методик для визначення складу порушення, пов'язаного 3 конфліктом інтересів, і відповідних заходів впливу за невиконання цих методик;

- залучення підлеглих до обговорення, розробки та ухвалення управлінських рішень, планів роботи, внесення пропозицій щодо покращення змісту, удосконалення певних напрямків роботи (сфер публічного управління);

- надання підлеглим консультативних та представницьких функцій, делегування їм прав і повноважень;

- професійно-кваліфікаційний та професійно-посадовий розвиток та розвиток кар'єри публічного службовця, застосування обгрунтованих критеріїв для підвищення рангів у межах певних категорій посад, переведення на нову посаду, присвоєння почесних звань і титулів, нагород, що є потужним стимулом до праці;

- професійне навчання та самоосвіта (Вікторов, \& Шпекторенко, 2007): участь у тренінгах, в роботі курсів підвищення кваліфікації, навчанні на робочому місці 3 видачею сертифікатів.

У формуванні професійних інтересів працівників публічних органів влади помітну роль відіграють інші заходи, наприклад, заходи соціального характеру з метою вирішення базових фізіологічних потреб: медичного обслуговування, страхування, оплата проїзних квитків, харчування, відпочинку. Оскільки у публічних службовців виражений інтерес у соціальній та професійній комунікації, то бажано створювати умови для виявлення ними громадської активності у неробочий час. Співробітники структурних підрозділів публічних органів влади прагнуть до неформального впливу, дружних контактів, тому комунікативні заходи у позаробочий час сприймаються ними дуже схвально.

\section{Висновки.}

Таким чином, у статті запропоновано двофакторну модель (цикл) формування професійних інтересів публічних службовців, засновану на акмологічному підході), яка дозволить здійснювати формування професійних інтересів публічних службовців 3 урахуванням соціального запиту. «Параметри активності» або ознаки суб'єктності людини, які професійне середовище органу публічної влади має сформувати у публічного службовця, мають переважно ціннісно-орієнтаційні якості, що спираються на самоусвідомленні компетентнісних якостей. 3 нашої позиції, завданням управління персоналом у галузі публічного управління $\epsilon$ циклічне використання стимулюючого та активізуючого резервів професійних інтересів у вигляді напрямів діяльності. Специфічними акмеологічними підходами в діагностиці (оцінюванні) професійних інтересів публічних службовців визначено: предметний; проблемний; ситуаційний та системно-генетичний.

Визначений автором комплекс практичних акмеологічних заходів для керівників органів публічної влади та керівників публічної служби дозволять повністю реалізувати освітньо-виховний та креативний аспекти структури рефлексивно-акмеологічного підходу до розвитку професійних інтересів публічних службовців. Професійне виховання як практична діяльність керівників передбачає розвиток у них таких якостей, як: власне суб'єктність - сформованість життєвої позиції «діяча», «керівника»; професійна научуваність, освіченість, а відтак - професійна компетентність; терпимість як розуміння цінностей іншої людини, як визнання інакомислення; функціональна грамотність.

Найголовнішими засобами та умовами формування професійних інтересів публічних службовців рекомендовані професійне виховання, професійне оцінювання, професійна орієнтація та власне мотивація. 
Процес формування професійних інтересів повинен бути спрямований на організацію професійної діяльності підлеглих, яка б активізовувала б їх до підвищення трудової віддачі. Для оволодіння таким підходом і застосування його на практиці керівник органу публічної влади або керів- ник публічної служби в органі влади мають володіти професійними компетентностями у проектуванні тих компонентів професійної діяльності своїх підлеглих (з позиції акмеології, це - світогляд, етичність та професійна поведінка, власне професійна діяльність).

\section{БІБЛІОГРАФІЧНІ ПОСИЛАННЯ:}

Акмеология: учебник / под общ. ред. А. А. Деркача; Рос. акад. госуд. службы при Президенте РФ; Междунар. акмеологический ин-т. Москва : Изд-во РАГС, 2004. 299 с.

Вікторов В. Г., Шпекторенко І. В. Самоосвіта державних службовців у навчанні за Професійною програмою підвищення кваліфікації : навч.-метод. посіб. Дніпропетровськ : ДРІДУ НАДУ, 2007. 38 с.

Деркач А., Зазыкин В. Акмеология : учеб. пособ. Санкт-Петербург : Питер, 2003. 256 с.

Зазыкин В. Г. Акмеографический подход в акмеологических исследованиях. Акмеология: методология, методы и технологии: мат-лы науч. сессии, посв. 75-летию чл.-корр. РАО, Президента МААН Н. В. Кузьминой. Відновлено 3: http://akmeolog.narod.ru/kus.html\#9.

Козлова Н. В. Личностно-профессиональное становление в условиях вузовского образования: акмеориентированный поход : автореф. дис. ... докт. психол. н. / ГОУ ВПО «Томский гос. ун-т», ГОУ ВПО «Томский политехнический ун-т». Томск, 2008. 44 с.

Магура М., Курбатова М. Секреты мотивации или мотивация без секретов. Москва : ИД «Управление персоналом», 2007. $656 \mathrm{c}$.

Севостьянов Д. А. Инверсивный анализ в управлении : монографія / Новосиб. гос. аграр. ун-т. Новосибирск : ИЦ НГАУ «Золотой колос», 2016. 287 с.

Федоркина А. П. Некоторые социально-психологические аспекты профессиональной деятельности госслужащих. Акмеология: методология, методы и технологии: мат-ль науч. сессии, посв. 75-летию чл.-корр. РАО, Президента МААН Н. В. Кузьминой. Відновлено 3: http://akmeolog.narod.ru/kus.html\#11.

Шпекторенко І. В. Професійна компетентність державного службовця. Університетські наукові записки: Часопис Хмельницького ун-ту управління і права. 2014. № 1 (49). С. 285-293.

Шпекторенко І. Структура професійної мобільності державного службовця. Актуальні проблеми державного управління: зб. наук. пр. Вип. 3 (29). Дніпропетровськ : ДРІДУ НАДУ, 2007. С. 211-220.

\section{REFERENCES}

Derkach, A., \& Zazyikin, V. (Eds.). (2003). Akmeologiya [Acmeology]. Sankt-Peterburg: Piter [in Russian].

Derkach, A. A. (Ed.). (2004). Akmeologiya [Acmeology]. Moskva: Izd-vo RAGS [in Russian].

Zazyikin, V. G. Akmeograficheskiy podhod v akmeologicheskih issledovaniyah [Acmeographic approach in acmeological researches]. Akmeologiya: metodologiya, metodyi i tehnologii: - Acmeology: methodology, methods and technologies: Proceedings of scientific session, dedicated to 75th anniversary of Corresponding Member RAO, IAEA President N. V. Kuzmina. Retrieved from http://akmeolog.narod.ru/kus.html\#9 [in Russian].

Kozlova, N. V. (2008). Lichnostno-professionalnoe stanovlenie v usloviyah vuzovskogo obrazovaniya: akmeorientirovannyiy podhod [Personal and professional formation in the conditions of higher education: an acmeoriented approach]. Extended abstract of doctor`s thesis. GOU VPO «Tomskiy gos. un-t», GOU VPO «Tomskiy politehnicheskiy un-t». Tomsk [in Russian].

Magura, M., \& Kurbatova, M. (2007). Sekretyi motivatsii ili motivatsiya bez sekretov [Secrets of motivation or motivation without secrets]. Moskva: ID «Upravlenie personalom» [in Russian].

Sevostyanov, D. A. (2016). Inversivnyiy analiz v upravlenii [Inverse analysis in management]. Novosib. gos. agrar. un-t. Novosibirsk: ITs NGAU «Zolotoy kolos» [in Russian].

Fedorkina, A. P. Nekotoryie sotsialno-psihologicheskie aspektyi professionalnoy deyatelnosti gossluzhaschih [Some social and psychological aspects of the professional activity of civil servants]. Akmeologiya: metodologiya, metodyi i tehnologii - Acmeology: methodology, methods and technologies: Proceedings of scientific session, dedicated to 75th anniversary of Corresponding Member RAO, IAEA President N. V. Kuzmina. Retrieved from http:// akmeolog.narod.ru/kus.html\#11 [in Russian]. 
Shpektorenko, I. V. (2014). Profesiina kompetentnist derzhavnoho sluzhbovtsia [Professional competence of the sovereign service]. Universytetski naukovi zapysky - University scientific notes, 1 (49), 285-293 [in Ukrainian].

Shpektorenko, I. (2007). Struktura profesiinoi mobilnosti derzhavnoho sluzhbovtsia [The structure of the professional mobility of the sovereign service]. Akt. problemy derzhavnoho upravlinnia - Actual problems of public administration, 3 (29), 211-220.

Viktorov, V. H., \& Shpektorenko, I. V. (2007). Samoosvita derzhavnykh sluzhbovtsiv u navchanni za Profesiinoiu prohramoiu pidvyshchennia kvalifikatsii [Self-education of civil servants in training according to the Professional program of advanced training]. Dnipropetrovsk: DRIDU NADU [in Ukrainian].

\section{Осипов Дмитро}

Аспірант

Дніпропетровський регіональний інститут

державного управління Національної академії

державного управління при Президентові України

Email: dioslaw5@gmail.com

\section{Osypov Dmytro}

Ph.D. Student

Dnipropetrovsk Regional Institute for Public Administration National Academy for Public Administration under the President of Ukraine

ORCID: 0000-0002-7132-5991

Цитування: Осипов, Д. (2020). Теоретико-практичні основи діяльності керівника у формуванні та оцінюванні професійних інтересів публічних службовців в Україні. Аспекти публічного управління, 8(3), 71-80. doi: 10.15421/152071

Citation: Osypov, D. (2020). Teoretyko-praktychni osnovy diialnosti kerivnyka u formuvanni ta otsiniuvanni profesiinykh interesiv publichnykh sluzhbovtsiv v Ukraini [Theoretical and practical bases of the head's activity in formation and estimation of professional interests of public servants in Ukraine]. Public administration aspects, 8 (3), 71-80. doi: 10.15421/152071

Стаття надійшла / Article arrived: 17.07.2020

Схвалено до друку / Accepted: 20.08.2020 